\title{
Helen Salisbury: Keeping politics out of the consulting room
}

\author{
Helen Salisbury GP
}

Oxford

Whatever my political views, I aim to be entirely neutral during a consultation. Patients come to me for medical advice, and my job is to diagnose, treat, empathise, and facilitate their route through illness and care. I try to be unremarkable: my views are irrelevant to the consultation, which is all about the patient. If patients sometimes forget whether they saw me or one of my colleagues I see it as positive-we're all doing a good enough job.

But, despite my best efforts, politics do intrude, brought by patients into many consultations. If I ask why my patient's depression has got worse, I may find that it's because her business is going bust and she blames Brexit. I sit and listen to desperate patients trying to navigate the maze of bureaucracy that will secure them the welfare benefits they need to live a decent life. I advise my patients about stopping smoking but, after cost cutting and outsourcing, the only services are two bus rides away and I know that they won't go.

In dealing with patients' immediate needs it can be difficult to look up and see the bigger picture

Often, I can focus on the more purely medical. Even then, having diagnosed a problem that isn't immediately life threatening but needs treatment from a hospital colleague, we discover that the next available appointment is four months away. My patient, understandably, asks why — and yet again I find myself apologising for the lack of service and saying something about funding.

When the surgery doors are closed I sit down at my computer to write letters. One provides more medical evidence to help a benefits or housing appeal. Another is a plea for a patient of mine who is in pain to have her surgery expedited. With your nose to the grindstone in dealing with patients' immediate needs it can be difficult to look up and see the bigger picture, let alone summon the extra energy to do anything about the root causes of their problems.

The US National Rifle Association recently caused an outcry when it told doctors that they should "stay in their lane" and stick to their own area of expertise rather than commenting on gun control. Doctors responded by posting pictures of their blood spattered surgical scrubs, graphically illustrating why this really was their business.

Here in the UK we won't necessarily agree about solutions to the problems facing our patients and the NHS, both locally and nationally, but we can bring trusted voices and very relevant experience to the debate. Neutrality is appropriate in the consulting room, but if we are to make our patients our first concern we also need to engage in the politics of health.

Competing interests: I am a GP partner, I teach medical students at Oxford University and St Anne's College, Oxford, and I answer readers' medical problems for Take a Break magazine. I am also a member of the National Health Action Party and serve on its national executive committee.

Provenance and peer review: Commissioned; not externally peer reviewed. Published by the BMJ Publishing Group Limited. For permission to use (where not already granted under a licence) please go to http://group.bmj.com/group/rights-licensing/ permissions 